\title{
PRODUCTIVITY, BIOLOGICAL EFFICIENCY, AND NUMBER OF Agaricus blazei MUSHROOMS GROWN IN COMPOST IN THE PRESENCE OF Trichoderma sp. AND Chaetomium olivacearum CONTAMINANTS
}

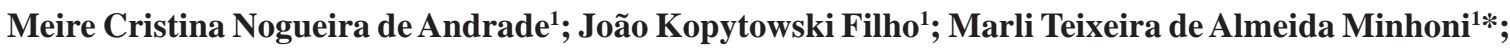 \\ Leila Nakati Coutinho²; Mário Barreto Figueiredo²
}

\begin{abstract}
${ }^{1}$ Universidade Estadual Paulista, Departamento de Produção Vegetal, Botucatu, SP, Brasil; ${ }^{2}$ Instituto Biológico, Centro de Pesquisa e Desenvolvimento de Sanidade Vegetal, São Paulo, SP, Brasil
\end{abstract}

Submitted: August 11, 2006; Returned to authors for corrections: December 07, 2006; Approved: March 19, 2007.

\begin{abstract}
This experiment was carried out to evaluate the effect of the fungi Trichoderma sp. and Chaetomium olivacearum on the productivity, biological efficiency and number of Agaricus blazei mushrooms grown in compost (mixture of crushed sugarcane, coast-cross grass trash, soybean meal, gypsum, and calcitic limestone). The experiment consisted of 3 treatments (Trichoderma sp., C. olivacearum, and a control) with 8 replications each (box containing $12 \mathrm{~kg}$ of compost colonized by A. blazei). Later, $150 \mathrm{~g}$ of inoculum of each contaminant fungus (Trichoderma sp. and C. olivacearum) were distributed on the surface of the compost previously colonized by $A$. blazei. The experiment was conducted in a greenhouse with a plastic roof, under relative humidity of about $60-90 \%$ and temperature between $20-34^{\circ} \mathrm{C}$. Productivity was determined from the relation between fresh weight of the mushroom and fresh weight of the compost. Biological efficiency was determined from the relation between fresh weight of the mushroom and dry weight of the compost at the end of the harvesting period. Based on results obtained, the contaminant fungi did not affect the productivity, biological efficiency, and number of A. blazei mushrooms grown in compost when introduced into previously colonized composts.
\end{abstract}

Keywords: Agaricus blazei, Chaetomium olivacearum, Trichoderma sp., contaminants

\section{INTRODUCTION}

The compost used to cultivate mushrooms of the order Agaricales is subject to the action of contaminant fungi, and their presence has been pointed out as one of the most important factors that frequently affect yield. During this process, competition occurs for space and nutrients, as well as chemical alterations in the substrate, which will hinder or prevent mushroom development. Among the most important contaminant fungi found in Agaricus blazei cultivations are Dactylium dendroides (cobweb disease), Trichoderma sp. (green and white mould), Chaetomium olivacearum (olive green mould), Papulospora sp., Peziza sp., and Diehliomyces microsporus (false truffle) (14).
The negative influence of contaminant fungi on the cultivation of several edible mushrooms is already known and has been studied for some years now $(1-3,6,8,10,11,17)$. Nevertheless, for A. blazei, most articles report on the occurrence and morphological characteristics of these fungi $(7,14)$, and only a few refer to their effect on mushroom production $(15,16)$. In this respect, Nascimento (14) verified that the presence of Diehliomyces microsporus in the compost or in the casing soil can reduce $A$. blazei productivity by up to $90 \%$.

Regarding C. olivacearum, compost or casing soil areas containing mycelium of this fungus are exclusory to A. blazei. The incidence of this contaminant agent frequently results from inadequate compost formulation, containing high nitrogen as

*Corresponding Author. Mailing address: Departamento de Produção Vegetal, FCA - UNESP. Fazenda Lageado, Caixa Postal 237. Rua José Barbosa de Barros, 1780. CEP 18603-970. Botucatu, SP, Brazil. Tel.: (14) 3811-7167 ou (14) 3811-7213. E-mail: modcogumelo@fca.unesp.br 
well as high moisture contents. These characteristics are further compounded by inappropriate management during composting phase II, characterized by deficient aeration and early filling of the compost in the tunnels. All these procedural errors are easily revealed by the presence of high ammonia contents in the compost, at the end of phase II. The fungus has a green olive color, but may also show gray to brown colors $(9,15,20)$.

Trichoderma sp., in turn, is very common during A. blazei colonization and production, especially in environments with deficient fresh air intake and circulation, in addition to high moisture, either in the compost, casing soil, or the air. At the initial stage, it appears in the form of white spots that generally become green due to sporulation of the fungus. In the compost, contaminants may occur in all A. blazei cultivation phases $(13,15)$. Like $C$. olivacearum, areas occupied by mycelium of this fungus become unfavorable to A. blazei mycelial growth.

There are no papers in the scientific literature evaluating the effect of Trichoderma sp. and C. olivacearum on A. blazei productivity. Consequently, the results presented in this experiment serve as a reference for future researches involving contaminant fungi.

The aim of this work was to evaluate the effect of the fungi Trichoderma sp. and C. olivacearum on A. blazei productivity, biological efficiency, and number of mushrooms.

\section{MATERIALAND METHODS}

\section{A. blazei, Trichoderma sp., and C. olivacearum inocula}

Pure fungal cultures were used for the production of A. blazei, Trichoderma sp., and $C$. olivacearum inocula, maintained as part of the Culture Collection of the Mushroom Research Center (Módulo de Cogumelos) of College of Agronomic Sciences/São Paulo State University (FCA/UNESP - Brazil).

A. blazei strain ABL 04/49 was used, originating in Porto Alegre/RS, reisolated from a basidioma from Mogi das Cruzes/ SP. The fungi Trichoderma sp. and C. olivacearum were isolated from contaminated composts and identified at Instituto Biológico, in São Paulo/SP.

\section{Substrate preparation, inoculation, and colonization}

The substrates used to produce the spawn were triticale grains (Triticum secale), gypsum, and limestone $(13,14)$. The grains were initially cooked in water for 40 minutes after the water started boiling. After draining the excess water, $20 \mathrm{~g} \mathrm{~kg}^{-1}$ of calcitic limestone and $160 \mathrm{~g} \mathrm{~kg}^{-1}$ of gypsum were added in relation to grain dry fresh weight. After homogenization, the substrate was placed in clear glass flasks, with a metal lid sealed with Tyvek ${ }^{\circledR}$ film. The flasks were autoclaved for 3 hours at $121^{\circ} \mathrm{C}$ and $1 \mathrm{~atm}$. Upon cooling, A. blazei, Trichoderma sp., and C. olivacearum were inoculated separately. Incubation was carried out in a BOD chamber at $28 \pm 1^{\circ} \mathrm{C}$ for 10 days, in the dark.

\section{Compost and Composting}

Composting phase I was performed in a covered hut with concrete floor, open sides, and natural ventilation. The ingredients used to formulate the compost consisted of $720 \mathrm{~kg}$ crushed sugarcane, $315 \mathrm{~kg}$ coast-cross grass trash, $117 \mathrm{~kg}$ soybean meal, $20 \mathrm{~kg}$ gypsum and $20 \mathrm{~kg}$ calcitic limestone, totaling $1,192 \mathrm{~kg}$ dry matter, as adapted from Kopytowski Filho (12). Prior to forming the windrow, the coast-cross grass straw was premoistened and turned every 2 days, for a period of 8 days.

The windrow was formed by depositing layers of crushed sugarcane and coast-cross (20 cm in height), followed by a layer of crushed sugarcane $(20 \mathrm{~cm})$ and so on until the windrow reached approximately $1.8 \mathrm{~m}$ in height by $1.8 \mathrm{~m}$ in width. A mixture was prepared separately, consisting of one half limestone and soybean meal (fresh weight), which was equitably added between the windrow layers. Irrigation was performed manually, with a hose, to maintain moisture around $70 \%$.

The compost was turned every three days. The second half of the mixture consisting of limestone and soybean meal (fresh weight) was added during the first turning. Gypsum was added in the subsequent turnings, and water was added whenever needed to maintain moisture at $70-75 \%$. Four turnings were performed, totaling 12 days in Phase I.

In phase II, the compost was transferred to polypropylene boxes, measuring $56.5 \times 46.5 \times 28.5 \mathrm{~cm}$ (length, width, and height). The boxes were randomly arranged inside a Dalsem container for pasteurization and conditioning. Pasteurization was performed for 6 hours at $61 \pm 1^{\circ} \mathrm{C}$ and conditioning was carried out for 13 days at $48 \pm 1^{\circ} \mathrm{C}$.

At the end of composting phases I and II, three compost samples were collected, dehydrated at $65^{\circ} \mathrm{C}$ for 48 hours and then ground in a knife mill with a 30 mesh sieve. According to FCA/UNESP Fertilizers and Correctives Laboratory, carbon and nitrogen contents, $\mathrm{C} / \mathrm{N}$ ratio, and $\mathrm{pH}$ in the samples at the end of composting phase I were $46.13 \%, 1.57 \%, 29 / 1$, and 6.64, respectively. At the end of Phase II, these values were $41.37 \%$, $2.28 \%, 18 / 1$, and 5.07, respectively.

\section{Inoculation and spawn run}

Inoculation was made by hand; $15 \mathrm{~g}$ A. blazei spawn were added per kg fresh compost. To accomplish this, the compost was apportioned and transferred to other smaller polyethylene boxes internally lined with transparent polyethylene plastic film containing holes in the bottom. The A. blazei spawn was added simultaneously and homogenized until reaching $12-12.5 \mathrm{~kg}$ fresh weight. After inoculation, the boxes were randomly arranged in a container and incubated in the dark for 15 days, at a compost temperature of $28 \pm 1^{\circ} \mathrm{C}$.

After that, $150 \mathrm{~g}$ of Trichoderma sp. or C. olivacearum inoculum were added to the compost, according to the treatments, and the casing soil was then added.

A loamy oxisol-alfisol from Fazenda Lageado was used as 
casing soil (FCA/UNESP). Initially, the $\mathrm{pH}$ was corrected to 7.0 by adding limestone ( $30 \mathrm{~kg}$ per $\mathrm{m}^{3}$ soil). The soil was moistened to $60 \%$ and left to rest for 20 days. Then, $30 \%$ wood charcoal (1$2 \mathrm{~cm}$ ) were added and pasteurization was carried out at $62^{\circ} \mathrm{C}$ for 8 hours, in a Dalsem container. The casing soil was sown over the surface of the compost by hand. Each box received about $15 \mathrm{~kg}$ casing soil, resulting in a thickness of approximately $4 \mathrm{~cm}$. The compost was covered with plastic and incubated for 15 days in a Dalsem chamber at $28 \pm 1^{\circ} \mathrm{C}$.

\section{Induction}

After the casing soil was colonized, the boxes were arranged at random in shelves inside a greenhouse with semi-controlled environment, constructed with an iron frame measuring $6 \mathrm{~m} \times$ $1.8 \mathrm{~m} \times 2.1 \mathrm{~m}$ (length, width, height, respectively) and covered with 150 micron AUV (Anti-Ultraviolet) plastic coating. Microsprinklers with a flow of $7 \mathrm{~L} \mathrm{~h}^{-1}$ were employed to control the relative humidity (60-90\%). The temperature ranged from 20 to $34^{\circ} \mathrm{C}$.

\section{Variables analyzed}

\section{Mushroom number and fresh weight}

The number and fresh weight of mushrooms (FWM) were determined daily during the harvesting phase.

\section{Productivity and biological efficiency}

Productivity $(\mathrm{P}, \%)$ was determined from the relation between mushroom fresh weight (FWM) and compost fresh weight (FWC) at the end of phase II, according to the equation: $\mathrm{P}=$ $\mathrm{FWM} / \mathrm{FWC} \times 100$.

Biological efficiency (BE, \%) was determined at the end of the harvesting period, according to the equation: $\mathrm{BE}=\mathrm{FWM} /$ DWC $\times 100$, where DWC corresponds to compost dry weight.

\section{Experimental Design and Statistical Analysis}

A completely randomized design was adopted, with three treatments and eight replicates. Each replicate corresponded to one box containing 12-12.5 kg wet compost. The data were submitted to analysis of variance and the means were compared by Tukey test (5\%) (17).

\section{RESULTS AND DISCUSSION}

Harvest started at 40 days for the control and Trichoderma sp. treatments (Figs. 1 and 2) and at 41 days for the $C$. olivacearum treatment (Fig. 3), after casing. This behavior is in agreement with results obtained by Braga (4), who verified the first flush on the 41st day. Kopytowski Filho $(12,13)$, in turn, started at 26 days after casing when producing in a controlled environment (14).

The inoculation of Trichoderma sp. and C. olivacearum into the compost already colonized by $A$. blazei did not affect productivity, biological efficiency, and number of mushrooms (Table 1). Even though results were not significantly different, the control group presented a tendency of better productivity (10.19\%) and biological efficiency (33.63\%), up to $22.03 \%$ and $22.06 \%$ higher as compared to the compost inoculated with $C$. olivacearum. Braga (4) tested cultivation rooms, compost weight, and casing soil thickness, and obtained productivities ranging from $9.36 \%$ - 15.76\%, while Kopytowski Filho (14)

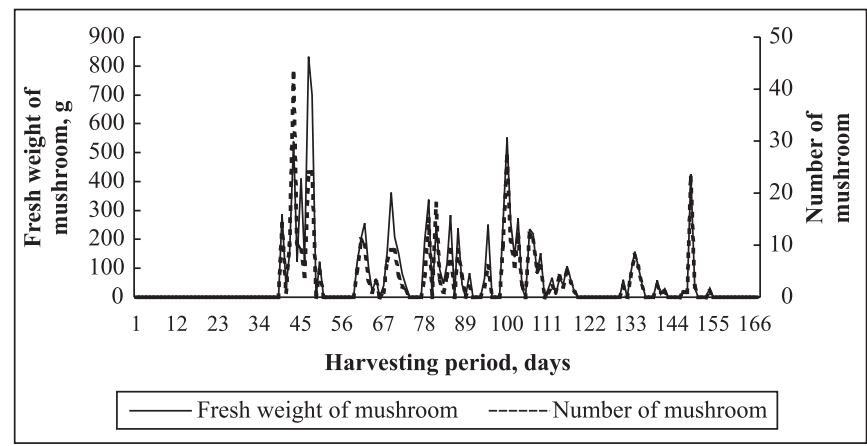

Figure 1. Fresh weight and number of mushrooms, based on a harvesting period of 167 days in the control treatment.

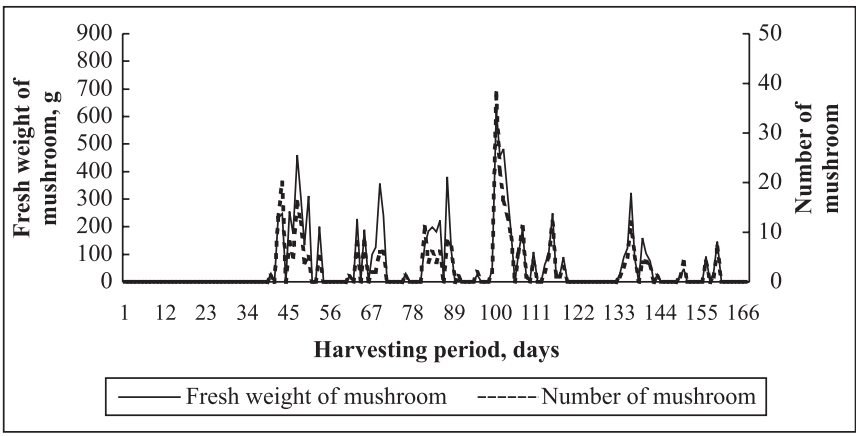

Figure 2. Fresh weight and number of mushrooms, based on a harvesting period of 167 days in the Trichoderma sp. treatment.

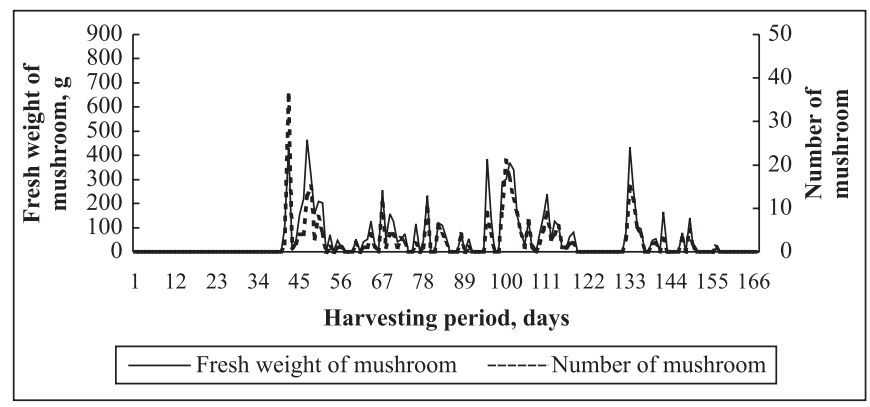

Figure 3. Fresh weight and number of mushrooms, based on a harvesting period of 167 days in the Chaetomium olivacearum treatment. 
obtained produtivities between 5.61 and $9.65 \%$ when testing compost supplementation.

Although a higher number of mushrooms was obtained in the control (34.88\% higher than the C. olivacearum treatment) it does not mean good profits for mushroom farms, since prices are usually based on the color, shape, and size of dehydrated mushrooms (14). Therefore, small mushrooms are associated with light-weight mushrooms. In our experiment, mean fresh mushroom weights were $23.62,24.71$ and $26.5 \mathrm{~g}$ for the control group, Trichoderma sp., and C. olivacearum, respectively.

In the control group (Fig. 1), the three greatest flushes occurred at 47, 100, and 149 days after casing, and corresponded to $832.45 \mathrm{~g}, 551.4$, and $425.5 \mathrm{~g}$ in fresh mushroom weight, respectively. In the Trichoderma sp. treatment (Fig. 2), these peaks occurred at 47, 100, and 102 days after the casing soil was added, and corresponded to fresh mushroom weights of 459.3, 625.2 , and $481 \mathrm{~g}$, respectively. In the C. olivacearum treatment (Fig. 3), however, these peaks occurred at 42, 47, and 133 days after adding the casing soil, and corresponded to fresh mushroom weights of $432.3,465$, and $433.7 \mathrm{~g}$, respectively.

The first flush occurred at the same time in the three treatments; however, fresh mushroom production obeyed an order of 46,29 , and $32 \%$ in relation to the total fresh weights produced in the control, Trichoderma sp., and C. olivacearum treatments, respectively (Figs. 1, 2, and 3). For mushroom farmers, shorter cultivation cycles mean faster investment return and reduced infestations of flies (13) and contaminants. In this experiment, all treatments showed several flushes, not defined in terms of duration and days after casing. This behavior is probably due to partial control of the environment, with both high and low temperatures in the same day, in addition to many changes in relative humidity. Nevertheless, A. blazei cultivation under environmental control can be carried out in 4-5 flushes lasting 3-5 days, with a cycle of up to 100 days after casing (14).

Damage resulting from the presence of contaminant fungi

Table 1. Total mean productivity values (mushroom fresh weight/ compost fresh weight), biological efficiency (mushroom fresh weight/compost dry weight), and number of Agaricus blazei mushrooms in the control, Trichoderma sp, and C. olivacearum treatments.

\begin{tabular}{lccc}
\hline Treatments & $\begin{array}{c}\text { Productivity } \\
(\%)\end{array}$ & $\begin{array}{c}\text { Biological } \\
\text { efficiency }(\%)\end{array}$ & $\begin{array}{c}\text { Number of } \\
\text { mushrooms }\end{array}$ \\
\hline Control & $10.19 \mathrm{~A}^{1}$ & $33.63 \mathrm{~A}$ & $54.63 \mathrm{~A}$ \\
Trichoderma $\mathrm{sp}$. & $8.70 \mathrm{~A}$ & $28.70 \mathrm{~A}$ & $44.50 \mathrm{~A}$ \\
C. olivacearum & $8.35 \mathrm{~A}$ & $27.55 \mathrm{~A}$ & $40.50 \mathrm{~A}$ \\
\hline
\end{tabular}

${ }^{1}$ Means followed by common letters in the columns do not differ by Tukey test (5\%). P: $\mathrm{CV}=30.93 \%, \mathrm{LSD}=3.54 ; \mathrm{BE}: \mathrm{CV}=30.95 \%$, $\mathrm{LSD}=11.69 \mathrm{NB}: \mathrm{CV}=40.54 \%, \mathrm{LSD}=23.78$. may become significant in situations in which they colonize the compost prior to A. blazei. Andrade (2) verified this behavior in a $L$. edodes cultivation. Eucalyptus logs submitted to high inoculum potentials of Trichoderma sp., Hypoxylon sp., Poria sp., and Stemonitis sp., prior to colonization by L. edodes, were unproductive. Jandaik et al. (10) evaluated the effect of $C$. dendroides on A. bisporus yield and reported reductions in the productivity and mean weight of mushrooms, as a result of an increase in $C$. dendroides inoculum density of $1-5 \mathrm{~g} \mathrm{~kg}^{-1}$ compost.

\section{CONCLUSION}

The contaminants $C$. olivacearum and Trichoderma sp. did not affect the productivity, biological efficiency, and number of A. blazei mushrooms grown in compost when introduced into previously colonized composts.

\section{RESUMO}

\section{Produtividade, eficiência biológica e número de cogumelos de $A$. blazei em composto na presença dos contaminantes Trichoderma sp. e C. olivacearum}

Foi avaliado o efeito dos fungos contaminantes Trichoderma sp. e C. olivacearum na produtividade, eficiência biológica e número de cogumelos da produção do A. blazei em composto (mistura de cana-de-açúcar, palha de capim coast-cross, farelo de soja, gesso e calcário calcítico). O delineanamento foi inteiramente casualizado com três tratamentos (Trichoderma sp., C. olivacearum e testemunha) e oito repetições (caixa com $12 \mathrm{~kg}$ de composto colonizado com A. blazei). Após a colonização do composto pelo $A$. blazei, adicionou-se $150 \mathrm{~g}$ de inóculo à base de triticale de cada um dos fungos contaminantes na superfície do composto seguido da camada de cobertura. O experimento foi conduzido em estufa com cobertura plástica, umidade relativa entre $60-90 \%$ e temperatura de $20-34^{\circ} \mathrm{C}$. A produtividade foi determinada pela relação entre a massa fresca de basidiomas e a massa úmida do composto. A eficiência biológica foi determinada pela relação entre a massa fresca de basidiomas e a massa seca do composto ao final do período de colheita. De acordo com os resultados obtidos, os fungos contaminantes $C$. olivacearum e Trichoderma sp. não afetaram a produtividade, eficiência biológica e número de cogumelos da produção do A. blazei em compostos previamente colonizados.

Palavras-chave: Agaricus blazei, Chaetomium olivacearum, Trichoderma sp., contaminantes.

\section{REFERENCES}

1. Andrade, M.C.N.; Graciolli, L.A. (2005). Controle de fungos contaminantes no cultivo do cogumelo comestível shiitake em toros de eucalipto. Acta Sci. Agron., 27(2), 293-299. 
2. Andrade, F.A. (1999). Efeitos de fungos contaminantes na produção de shiitake (Lentinula edodes (Berk) Pegler) em toras de Eucapyptus saligna Sm. Botucatu, Brasil, 61p. (M.Sc. Dissertation. Faculdade de Ciências Agronômicas. UNESP).

3. Beyer, D.M.; Kremser, J.J. (2004). Evaluation of fungicide tolerance and control for three fungal diseases of mushrooms. In: Romaine, C.P., Keil, C.B., Rinker, D.L., Royse, D.J. (eds). Science and cultivation of edible and medicinal fungi - Mushroom Science XVI. Penn State University, University Park, USA, p.521-529.

4. Braga, G.C. (1999). Produtividade de Agaricus blazei Murrill em função do ambiente de cultivo,peso fresco do substrato e camada de cobertura. Botucatu, Brasil, 73p. (Ph. D. Thesis. Faculdade de Ciências Agronômicas. UNESP).

5. Bononi, V.L.R.; Capelari, M.; Trufem, S.F.B., Maziero, R. (1995). Cultivo de cogumelos comestíveis. Ícone, São Paulo, SP.

6. Chen, A.W.; Moy, M. Mushroom cultivation: building mold contamination. In: Romaine, C.P., Keil, C.B., Rinker, D.L., Royse, D.J. (eds). Science and cultivation of edible and medicinal fungi Mushroom Science XVI. Penn State University, University Park, USA, p.625-632.

7. Coutinho, L.N.; Andrade, M.C.N.; Figueiredo, M.B.; Kopytowski Filho, J.; Minhoni, M.T.A. (2006). Mildio em cogumelos cultivados (Agaricus blazei) no estado de São Paulo. XXIX Congresso Paulista de Fitopatologia, Botucatu, SP, p.21.

8. Figueiredo, M.B.; Mucci, E.S.F. (1985). Doenças e pragas do cogumelo comestível (Agaricus campestris L.). Biológico, São Paulo, SP. 51(4): 93-111.

9. Griesven, L.J.L.D. (1988). The cultivation of mushrooms. Mushroom experimental station, Horst, Netherlands.

10. Jandaik, S.; Guleria, D.S.; Parmar, Y.S. (2004). Effect of Cladobotryum dendroides on the yield of Agaricus bisporus: Inoculum factors and timing of infection. In: Romaine, C.P., Keil, C.B., Rinker, D.L., Royse, D.J. (eds). Science and cultivation of edible and medicinal fungi - Mushroom Science XVI. Penn State University, University Park, USA, p.503-505.
11. Kalberer, P.P. (2001). Water relations of the mushroom culture (Agaricus bisporus: influence on the crop yield and on the dry matter content of the fruit bodies. In: Maher, M.J. (ed.). Science and cultivation of edible and medicinal fungi - Mushroom Science XI Balkema, Rotterdam, p.269-74.

12. Kopytowski Filho, J. (2002). Relação $C / N$ e proporção de fontes nitrogenadas na produtividade de Agaricus blazei Murrill e poder calorífico do composto. Botucatu, Brasil. 97p. (M. Sc. Dissertation. Faculdade de Ciências Agronômicas. UNESP).

13. Kopytowski Filho, J.; Minhoni, M.T.A. (2004). Nitrogen sources and $\mathrm{C} / \mathrm{N}$ ratio on yield of Agaricus blazei. In: Romaine, C.P., Keil, C.B., Rinker, D.L., Royse, D.J. (eds). Science and cultivation of edible and medicinal fungi - Mushroom Science XVI. Penn State University, University Park, USA, p.213-220.

14. Kopytowski Filho, J. (2006). Produtividade e eficiência biológica de Agaricus blazei (Murrill) Heinemann, em diferentes condições de cultivo. Botucatu, Brasil. 134p. (Ph. D. Thesis. Faculdade de Ciências Agronômicas. UNESP).

15. Minhoni, M.T.A.; Kopytowski Filho, J., Andrade, M.C.N. (2005) Cultivo de Agaricus blazei Murrill ss. Heinemann. FEPAF, Botucatu, SP.

16. Nascimento, J.S. (2003). Etiologia, controle e demanda de energia na prevenção da falsa trufa (Diehliomyces microsporus) em cultivos de Agaricus blazei. Botucatu, Brasil, 115p. (Ph. D. Thesis. Faculdade Ciências Agronômicas. UNESP)

17. Nascimento, J.S.; Eira, A.F. (2003). Occurrence of the false truffle (Diehliomyces microsporus Gilkey) and damage on the himematsutake medicinal mushroom (Agaricus brasiliensis S. Wasser et al.). Int. J. Med. Mushr., 5(1), 87-94.

18. Przybylowicz, P.; Donoghue, J. (1990). Shiitake grower's handbook: the art and science of mushroon cultivation. Kendall, Dubuque.

19. Snedcor, G.W.E.; Cochran, W.G. (1972). Statistical methods. The Iowa State University Press, Ames.

20. Vedder, P.J.C. (1996). Cultivo moderno del champignon. Mundi prensa, Madrid. 